\section{FAZEKAS Dóra}

\section{AUKCIÓK AZ EURÓPAI UNIÓ SZÉN-DIOXID-KERESKEDELMI RENDSZERÉNEK PRÓBAIDŐSZAKÁBAN}

Jelen cikk az Európai Unió szén-dioxid-kibocsátás kereskedelmi rendszerének próbaidôszakában lezajlott aukciókat elemzi. Ezek lebonyolításának vizsgálata és a tapasztalatok megismerése különösen fontos, nemcsak a kiotói idốszakra való felkészüléshez, hanem a 2013 utáni nagyarányú árverések lebonyolításának kialakításához is. A próbaidôszakban négy tagállam tett félre kibocsátási egységeket nemzeti kiosztás tervében, hogy azokat térítés fejében ossza ki. Három ország - Írország, Magyarország és Litvánia - borítékolt, egyenáras árverést rendezett. A dán kormány pedig közvetlenül a piacon értékesítette egységeit. Az árverések sikeresen lezajlottak, azonban egyik tagállam sem tudott igazán profitálni a rendszerból a szén-dioxid-egységek árának mélyrepülése miatt.

Kulcsszavak: aukció, szén-dioxid-kibocsátási egység, borítékolt, egyenáras árverés

A 2003/87/EC EU-s direktívának megfelelóen a tag- különbségek és hasonlóságok, valamint a megvalósítás államok az Eưópai Unió szén-dioxid-kibocśtás ke2007) 5\%-ot, a kiotoi idószakban (2008-2012) $10 \%$ ot tartalékolhatnak a piacon való közvetlen értékesít céljábó

2008-tól több tagállam nagyobb mértékben árverez el egységeket, vagy ertékesit közvetlenül a piaco A bizottság álláspontja szerint az aukcióknak nyíltnak kell lenniük, hogy bárki licitálhasson a kibocsátási egységekért (COM/2006/0725).

Az EU Bizottsága 2008. január 23-án hagyta jóvá azt a javaslatot (COM/2008/0016), mely a 2013-tól kezdôdó idôszakra változtat a rendszeren. 2008. december 17-én megallapodtak a tagállanok, hogy 2013-tól az az egységeket. A tézsogek elkentlése édekében fokozatosan vezetik be az árveréseket. 2013-ban 30\%-k indulnak, s lépésenként jutnak majd el a teljes aukció hoz 2020-ra, más szektorokban pedig a 2013-as 20\%-

Jelen tanulmány első fejezete áttekintést nyújt az aukciók elméleti hátterérốl. A második fejezet a próbaidőszakban lezajlott aukciók típusát és jellemzốt taglalja: sor kerül a terítéses kiosztásban mutatkozo módjának és időzítésének bemutatására is.

\section{Elméleti háttér}

A közgazdasági szakirodalom széles köre foglalkozik az aukciók elméletével s megvalósításuk jellemzóivel. Az Auctions: Theory and Practice (Klemperer, 2004) könyv áttekinti az elméletet. Azon olvasóknak, akik Economic Theory of Auctions (Klemperer, 2000) címú könyvet ajánlom

Az aukciók környezetvédelmi megvalósításával már többen is foglalkoztak (Cason, 1995; Cason Plott, 1996; Joskow - Schmalensee - Bailey, 1997). sioxid-rendszer

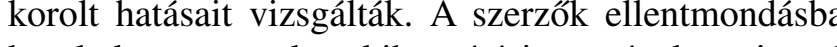
kerültek - egyesek a kibocsátási egységeket piaccal rendelkezó jószágoknak tekintették, míg mások ezt tagadták. Cason és Plott (1996) veleménye szerint az aukciós szabályok arra ósztōnzik a piac szereplóit mind az eladókat, mind a vevóket -, hogy alulbecsüljék kibocsátáscsökkentesi költségeiket. A szerzók szerint az amerikai $\mathrm{SO}_{2}$-aukciók alacsonyabb piactisztító árakhoz vezetnek, s ezáltal kisebb hasznot hoznak a résztvevókreskedelmi rendszerének (European Union Emissions Trading Scheme - EU ETS) próbaidőzzaḱn Én' (2005Trading Scheme - EU ETS) probbaidószakában' (200517-én megállapodtak a tagállamok hogy 2013-tól az energiaszekk ról jutnak majd el 70\%-hoz 2020-ra. részletesebben kívánnak elmélyülni a témában, a The aukcioinak jellemzóit, hiányosságait, s piacra gya- nek (p. 157.). Joskow, Schmalensee és Bailey (1998) viszont kritizálja Cason és Plott elméleti eredményeit, s rámutatnak, hogy a valóságban nem figyelhetók me az általuk leírtak. Joskow, Schmalensee és Bailey szerint az aukciók elérték elsódleges céljukat, azaz ösztönözték a piaci kereskedés kialakulását (p. 22.)

Késóbbi tanulmányok (Klemperer, 2002; Mandell, 2005) kifejezetten a $\mathrm{CO}_{2}$-piacra fókuszáltak. $\mathrm{A} \mathrm{CO}$ aukciók lebonyolítása lehet egyszeri (single auction approach): az adott idôszak elején árverezik el az öszszes rendelkezésre álló egységet, vagy értékesíthetnek a kormannyok többszôn is adott idôszakban (multipleauction approach). Minél gyakoribbak az aukciók, annál rovidebb idôre tudnak a cégek elóre tervezn ez pedig magasabb tranzakciós költségekhez vezet, ugyanakkor könyíti a cash-flow tervezését (Mandell 2005). Ez a megállapitás jelentós az EU ETS-beli aukciók időzítése szempontjából. A próbaidôszakban egyil tagállamban sem voltak gyakori aukciók, sốt utólag beigazolódott, hogy az a tagállam jutott a legnagyobb bevételhez, amelyik az idôszak elején értékesítette legtöbb egységet.

A $\mathrm{CO}_{2}$-piac likviditásától s az egységek szúkösségétốl fügoóen négy eset képzelhetô el, s négy javaslat fogalmazható meg az egységek aukciós értékesítéséró (Cook et al., 2005):

(1) az EU ETS likvid piac és a felesleg szúkös az állam a jelenlegi piaci áron értékesítsen (ún. market order),

(2) az EU ETS likvid piac és a felesleg jelentôs - az állam a jelenlegi piaci áron értékesítsen több menetben (ún. sequence of market orders),

(3) az EU ETS nem likvid piac és a felesleg szúkös - egyenáras, zárt aukció,

(4) az EU ETS nem likvid piac és a felesleg jelentố - emelkedő áras nyílt aukció

A szerzók összességében emelkedő áras, nyílt aukciót javasolnak, amennyiben az értékesíthetố mennyiség az átlag napi piaci forgalom 5\%-a és a várt bevetel nagysága eléri a kétmillió angol fontot az aukció idôpontja elôtt egy hónappal. Amennyiben e feltétele nem teljesülnek, több tételben kell az egységeket a piacon értékesíteni.

1. táblázat

Aukciótípusok áttekintése

\begin{tabular}{|l|l|l|l|l|}
\hline \multicolumn{3}{|c|}{ Statikus (borítékolt, zárt, vagy vak) aukció } & \multicolumn{2}{c|}{ Dinamikus (nyílt) aukció } \\
\hline \multirow{3}{*}{ Egyen áras aukció } & $\begin{array}{l}\text { Ajánlati áras, borítékolt } \\
\text { legmagasabb áras aukció }\end{array}$ & $\begin{array}{l}\text { Borítékolt második } \\
\text { legmagasabb áras aukcióó } \\
\text { Vickrey aukció }\end{array}$ & $\begin{array}{l}\text { Emelkedó áras aukció, } \\
\text { nyít aukcióo, } \\
\text { kikiáltásos aukció, } \\
\text { angol vagy japán aukcióó }\end{array}$ & $\begin{array}{l}\text { Csökkenó áras aukció, } \\
\text { holland aukció }\end{array}$ \\
\hline
\end{tabular}
A sikeres árverések megrendezéséhez a következ
ritériumoknak kell teljesülniük (Cook, 2005):

a termék homogén, osztható egységekból áll,

a ternéknek múködik másodlagos piaca,

Az EU ETS egységek (European Union Allowances EUA) mindhárom kitételnek eleget tesznek:

A szén-dioxid egyenletesen eloszló, a légkörben felgyülemlő szennyező anyag. Környezetvédelmi szempontból sem a kibocsátás helye, sem ideje nem fontos. A kibocsátási egységek egyformák az EU minden tagállamában s minden szektorában. Az egységeket $\mathrm{CO}_{2}$ tonnákban mérik.

- Az EUA-knak van másodlagos piaca.

- A szén-dioxid-piac nem koncentrált. Még a legnagyobb piaci szereplók is kicsik a piac egészépraci piaci szereplo a teljes piaci mennyiség mindössze , 2007). Még a legnagyobb energiaszektornak sincs igazi piaci ereje.

Kéttípusú aukciót különböztethetünk meg (l. 1. táblázat): statikus és dinamikus aukciót. A fố különbség a fordulókban rejlik, a dinamikus aukciókban több forduiket, a statikusban nem. Az emelkedó áras aukcióban a kíro határozza meg az árat, az ajánlattevớk pedig a kívant mennyiségekre licitálnak. Az egymást követô for作ban emelkedik a kikiáltási ár, s ezzel párhuzamoan csökken a kereslet mindaddig, míg meg nem egyezik z eladásra kínált mennyiséggel. Noha az emelkedó áras aukció igen átlátható, megvalósítása drága és bonyolult (Macken, 2006). Valószínúleg emiatt nem alkalmazták az EU ETS egyik árverező tagállamában sem. Ugyan az Egyesült Királyság kibocsátáskereskedelmi rendszerékus aukción értékesítette az ÜHG-egységeket, valamint az amerikai Clear Skies törvény is dinamikus aukciót javasolt az SO-, NO- és -higany kibocsátási egységek endszerében, az optimális aukciós technika a zárt, egyenáras aukció, egyszerúsége s átláthatósága miatt amton - Kerr, 2002; Cook et al., 2005). szes rendelkezesre alló egyseget, ugy ertekesithetnek 
A statikus aukció adminisztratív kezelése egyszerú, a piactisztító ár ( $P^{*}$ az l. ábrán) automatikusan kialakul, mikor az értékesítésre kínált mennyiség (kínál - S) éppen megegyezik az ajánlattevơk által megvásárolni kívánt mennyiséggel (kereslet - D). A P* áro vagy afölött tett ajánlatok mind nyernek. A zárt aukcióknál három árazási mechanizmust különböztethetün meg: (1) egyenáras auk

(1) Az egyenáras aukció a gyakorlatban leggyakrabban alkalmazott árazási mechanizmus, a legacsonyabb még nyertes ajánlat ára határozza meg az aukciós árat.

(2) Az ajánlati áras aukcióban minden ajánlattevố azt az árat fizeti meg, amennyit ô licitált.

(3) A Vickrey aukció a legbonyolultabb, a nyertese annak haszonáldozati költségét fizetik meg, hogy az adott termék éppen az övék lett, azaz a második legmagasabb árat fizetik érte.

Keresleti görbe

(Cramton-Kerr, 2002)

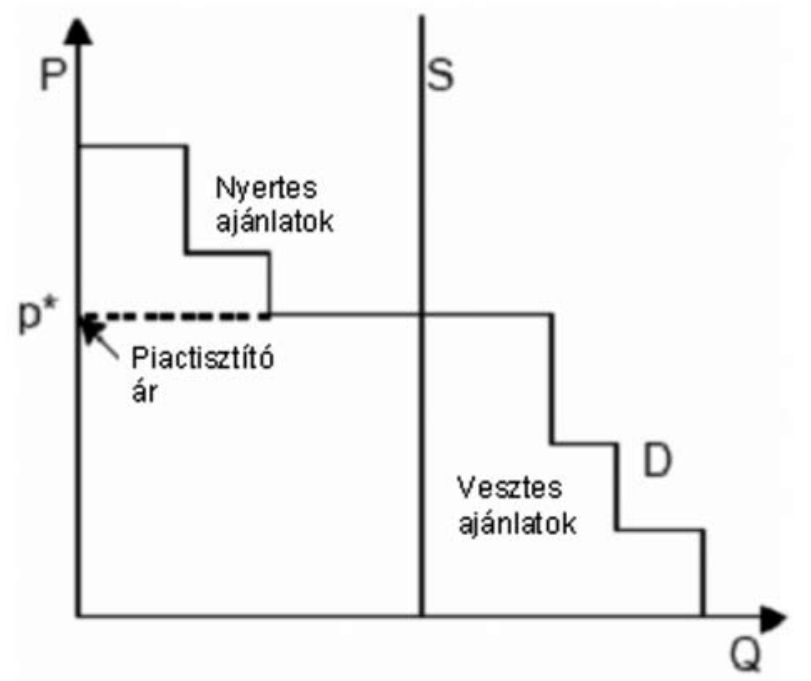

A fentiekben bemutatott aukciós technikák közül mánk szempontjából kettőnek van gyakorlati jelensége: (1) a statikus zárt, $\mathrm{s}$ (2) a dinamikus emelkedô aras aukciónak. A különbség a kettő között annyi, hogy hány fordulóban licitálhatnak a résztvevő́k. A statikusban egyetlen fordulóban dól el az aukció. Az ajánlattevốk egységárakra és a keresett mennyiségre tesznek ajánlatot. A nyertes az, aki a legmagasabb árú ajánlatot tette. Nem véletlen tehát, hogy egyszerúsége miatt az EU ETS minden árverező tagállama egyenáras zárt aukciót valósított meg.

Az aukciós elméletek áttekintése után a következô fejezetben vizsgáljuk meg az Európai Unió széndioxid-kibocsátás-kereskedelmének próbaidőszakában lezajlott aukciókat.

\section{A próbaidôszakban lezajlott aukciók}

A huszonöt, majd huszonhét EU-tagállamból mindöszsze négy ország különített el aukciós célra kibocsátási egységeket. A 2. táblázat mutatja, mennyit tartalékoltak nemzeti kiosztási terveikben az egyes országok, s hogy végül mennyit értékesítettek a próbaidőszakban. Írország és Magyarország több egységet árverezett el mint amennyit félretettek, a különbséget az új belépók tartaćkából, illetve a bezáró létesítmények egységeiból fedezték.

Fontos kitérni a dán értékesítésre, mert a kiotói idôszakban több tagállam fog közvetlenül a piacon értékesíteni. A közvetlen piaci értékesítés, vagyis a szervezett európai tőzsdéken történő eladás több szempontból is más, mint az árverésen történó értékesítés.

(1) Az árveréseken általában nagyobb kereslet koncentrálódik egy adott idốpontban, mint amekkora a tőzsdéken jelentkezik ugyanazon időszakban. Az árveréseken nagyobb mennyiséget értékesítenek, mint a nap tőzsdei kereskedése.

Aukciós tartalékok és elárverezett egységek

\begin{tabular}{|c|c|c|c|c|c|}
\hline Aukciós tartalék & EU-25 & Dánia & Írország & Magyarország & Litvánia \\
\hline \multirow{2}{*}{$\begin{array}{c}\text { Próbaidószak } \\
\%\end{array}$} & 7499201 & 5025000 & 502201 & 1420000 & 552000 \\
\hline & & $5 \%$ & $0,75 \%$ & $2,5 \%$ & $1,5 \%$ \\
\hline \multicolumn{6}{|c|}{ Elárverezett egységek } \\
\hline & & & 250000 & & \\
\hline 2006 & 5172500 & 2762500 & 963000 & 1197000 & 0 \\
\hline 2007 & 3348000 & 1618500 & 0 & 1177500 & 552000 \\
\hline 2008 & 445000 & 0 & 445000 & 0 & 0 \\
\hline Próbaidószak & 8965500 & 4381000 & 1658000 & 2374500 & 552000 \\
\hline$\%$ & & $4,35 \%$ & $2,47 \%$ & $4,18 \%$ & $1,5 \%$ \\
\hline
\end{tabular}

VEZETÉSTUDOMÁNY
(2) Az árverésen való részvétel költsége a vásárlók számára alacsonyabb, mint a tôzsdék, brókerházak szolgáltatásainak igénybevétele.

(3) Az árverésekre ritkábban kerül sor, a befolyó pénz nagysága kockázatosabb, mint a közvetlen piaci értékesítésből várható összbevétel.

Dánia

Dánia több mint ötmillió kibocsátási egységet tartalékolt aukciós célból a próbaidôszakban, amely a teljes nemzeti kiosztható mennyiség 5\%-a. Eredetileg minnemzeti kiosźn denki számára hozzán - a dán kincstár vagyonát növelték volna. Azonban a dán kormány végül nem bocsátotta aukcióra a félretett dán kormány vegull nem bocsátotta aukcióna a félretent egységeket, hanem bevételeik maximalizálása érdekében a közvetlen piaci értékesítés mellett döntötte A dán Klíma- és Energia Minisztérium fơtanácsadója, Sigurd Lauge Pedersen elmondása alapján a dán döntés mögött az a feltételezés állt, hogy egy bróker tudja a legnagyobb nyereséggel a piacon értékesíteni az egységeket. Legalábbis annál mindenképpen jobban, mond a tanácsadó, ahogy egy nem szakértő kormánytisztviselő tennét.

2006 május végén írta ki a dán környezetvédelmi ügynökség a tendert, majd október elején szerződtek

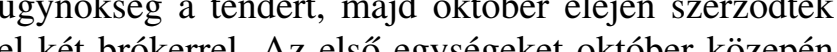
értékesítték. A bróker az egységeket közvetenïr a regiszterbOl kapthk a forwa piaco nog

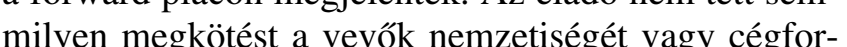
milyen megkötest a vevôk nemzetisegét vagy cégformaját illetôen (Pedersen, 2007). A dân kormany 2762 ezer tonna egységet értékesített a piacon 2006-ban, amikor az árak 0,9 és 2,2 euró között mozogtak. További ertékesítesekre került sor egeszen 2008. április 30-ig. A próbaidőszak végére 644000 egység marad a dán számlán felhasználatlanul. Kizárólag az aukciós tartalékot értékesítették, sem az új belépók tartalékához, sem a bezáró létesítmények egységeihez nem nyúltak a brókerek, így ezek elvesztek (Pedersen, 2007).

Ugyan a közvetlen piaci értékesítés nem biztosítja ugyanazt az árjelzést, mint az aukcionálás, ez nem jelentett hátrányt, hiszen az árak nyilvánosak voltak a kereskedési platformokon. Az árak bizonytalansága miatti kockázatot a közvetlen értékesítés csökkentette, hiszen az aukció bejelentése s megrendezése közötti idôszzak alatti árváltozás jelen esetben nem okozo problémát. A dán közvetlen értékesítés mennyiségekkel súlyozott ára magasabb volt, mint az idôszak piaci átlagára. Megállapíthatjuk, hogy jobban járt a dán kormány a brókereken keresztüli értékesítéssel, mintha az átlag piaci áron értékesítette volna egységeit.

\section{rország}

Írország rendezte meg az első aukciót az EU ETSben. Eredetileg 502201 egységet tartalékoltak kiosztási tervükben, amely a teljes kiosztási mennyiség $0,75 \%$-a. Végül három aukción több mint másfél millió egységet ertékesítettek (a teljes mennyiség mintegy 2,5\%-a). A többletet a bezáró létesítmények egységeiből, valamint a fel nem használt új belépôs tartalékból fedezték. A kockázatok csökkentése érdekében nem hozták nyilvánosságra a rezervációs árat (ún. non-disclosed), súgy döntöttek, két körben rendeznek árveréseket. Az elsó árvést 2006 jun jónco a cemberben, utoljára pedig nem sokkal az idôszak lezáa gott, ekkor jelentós bevételre tett szert az ir kormány. 2008. március 6-ân kínálta értékesitésre az ír környezetvédelmi ügynökség a megmaradt egységeket, 445 EUA-t.

Az EU ETS regisztereiben számlával rendelkezők licitálhattak az árveréseken, 500 egységenkénti tételekben. A rendszer adminisztratív költségeinek fedezésére szolgált az aukció minél szélesebb körü elérhetősége, mely ugyanakkor spekulációs ajánlattételre adhat lehetőséget, $\mathrm{s}$ az ajánlatok értékelését is nehezíti. $\mathrm{E}$ kockázatok kiküszöbölése érdekében vezették be az előminő́śtés követéne ét, ir rencerte az (r) (Macken, 2007). Letétet mindhárom ország megkövetelt ugyan, de elóminősítés csak lrországban volt. Az elóminósités során 3000 eurós letétet követeltek meg az ajánlattevóktóll, annak reményében, hogy ez elrettenti a nem komoly szándékú vevôket. A letétet a nyertesekkel fizettették meg, a vesztes ajánlattevőknek pedig visszafizették az összeget. Azok a nyertes licitálók pedig, akik végül nem éltek vásárlási szándékukkal, elvesztették a pénzt.

\section{Litvánia}

Litvániában a litván környezetvédelmi befektetési alap 552000 EUA-t kínált értékesítésre. Az online aukciót 2007. szeptember 10-én rendezték, az EU sén-dioxid-kereskedelmi rendszerében utolsóként. A piaci ár nem kedvezett a litvánoknak, mindössze 6 eurócent volt akkoriban. Az összes bevétel 33120 euró lett, ami még a lebonyolítás adminisztratív költségeit sem fedezte. Ebból a szempontból nem volt szerencsés a kivárás taktikáját alkalmazni. Ugyanakkor tulajdonképpen egyik ország sem használta ki maximálisan a bevételgenerálás lehetôségét, hiszen csak 2006-ban, az arak mélyrepülése után bonyolították le az aukciókat.

Az aukciót a magyar Vertis Kft. bonyolította le a Climex kereskedési platformon. Az ajánlatokat egy órán 
keresztül lehetett megtenni, ez idó alatt módosíthatták sốt vissza is vonhatták tétjeiket a résztvevớk, késốb viszont már nem. Az aukció zárt volt, nem láthatták licitálók egymás ajánlatait. Hasonlóan a magyar árveréshez a legalacsonyabb nyertes ajánlati ár határozta

meg az aukciós árat - minden ajánlattevő ezen az
vihette haza szén-dioxid-kibocsátási egységeit.

\section{Magyarország}

Magyarország a próbaidószaki nemzeti kiosztási tervben 2,5\%-os aukciós tartalékot határozott meg (66/2006os kormányrendelet). Azaz mintegy évi 790000 tonnát tett félre a magyar állam, hogy pénzért értékesítse az EU ETS próbaidőszakában. 2,4 millió egységet értékesítettek végül két aukción, ami a teljes mennyiség több min 4\%-a. Az aukciós tartalékon kívül a fel nem használt ú belépók tartalékát és a bezáró létesítmények miatt felszabadult egységeket is értékesítették.

Az elsố aukciót 2006. december 11-én tartotta a Pénzügyminisztérium. 1197000 kibocsátási egységet árvereztek el tonnánként 7,42 eurós áron. Ez 2,275 milliárd forint költségvetési bevételt jelentett. ${ }^{5}$ A lebonyolítás során a környezetvédelmi és a pénzügyi szaktárca szembekerült egymással. A KvVM az aukciók miné hamarabbi lebonyolítását szorgalmazta, s utólag az ár zuhanása miatt joggal rótta fel a lebonyolítóknak, hogy zunarsa jogk csakdecemberbenkerültekárveresreafélretettegységek. A második aukció 2007. március 26-án kerult megrendezésre. 1177 500 egységet értékesítettek tonnánként 0,88 eurós áron. A teljes bevétel 255,62 millió forint volt.

$\mathrm{Az}$ aukciókat a magyar euets. com $\mathrm{CO}_{2}$ kereskedelmi platformo bonyolították le. Az EU ETS regisztereiben számlával rendelkezók licitálhattak. Eredetileg két fordulót tervezett a Pénzügyminisztérium, de már az elsố körben elkelt a teljes mennyiség mind a decemberi, mind a márciusi kiiŕskor. Az aukció egyenáras volt, az aukciós au ció egyenaras volt, az aukciós arat a legalacsonyabb még elfogadot ár határozta meg (ún. piactisztíto ar). A REKK (2006) elôzetes tanulmányával összhangban a magy allam minimalárat határozott meg (l. 4. táblázat). Az ajánlattevớk előre meghatározott idôszakban tehették meg tétjeiket, $\mathrm{s}$ az idôszak lezárta után nem vonhatták vissza azokat. Az ajánlattevớk nem láthatták egymás licitjeit, ezért is hívjuk ezt vak, illetve zárt aukciónak. Ajánlatot a megvásárolni kívánt mennyiség ellenér- tékének teljes pénzügyi fedezetével lehetett tenni. Az aukció elốtt két munkanappal kellett az euets.com kereskedési platformon, vagy a Climex szövetség bármely tagjánál elhelyezni az összeget. A tranzakciókat az aukciót követô két munkanapon belül írták jóvá a résztvevớk számláin.

A 109/2006. kormányrendelet írja elő az értékesítés szabályait. A vagyonkezelônek kell a gazdasági és közlekedési miniszter egyetértésével javaslatot kidolgoznia az értékesítés rendszerességére, idốpontiára, valamint az értékeśtendó mennyiségre vonatkozón. Ezt a pénzügyminiszternek jóvá kell hagynia, s ezt követó-

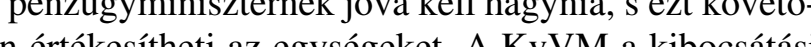
gységek êrékesitesentek rendszeressegere, idôpontjá-

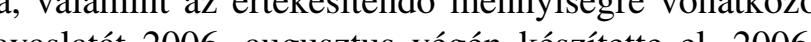
javastatá 2006. augusztus végén keszitette el. 2006. . niszter egyetértését, ami 2006. október elején érkezett meg a KvVM-be. 2006. október 10-én kezdeményezte a környezetvédelmi miniszter az értékesítést a pénzgymminiszternél. 2006. november 27-én a 109/2006. (V. 5.) kormányrendelet értelmében a magyar kormány bejelentette árverezési szándékát. 2006. december 11én pedig sor került az első árverésre. Az értékesítési javaslat elkészülte és az aukció között eltelt több mint három hónap - ez jelentósen alacsonyabb árat eredmé-

A CO-egységek árának alakulás Forrás: Kaderják, 2007

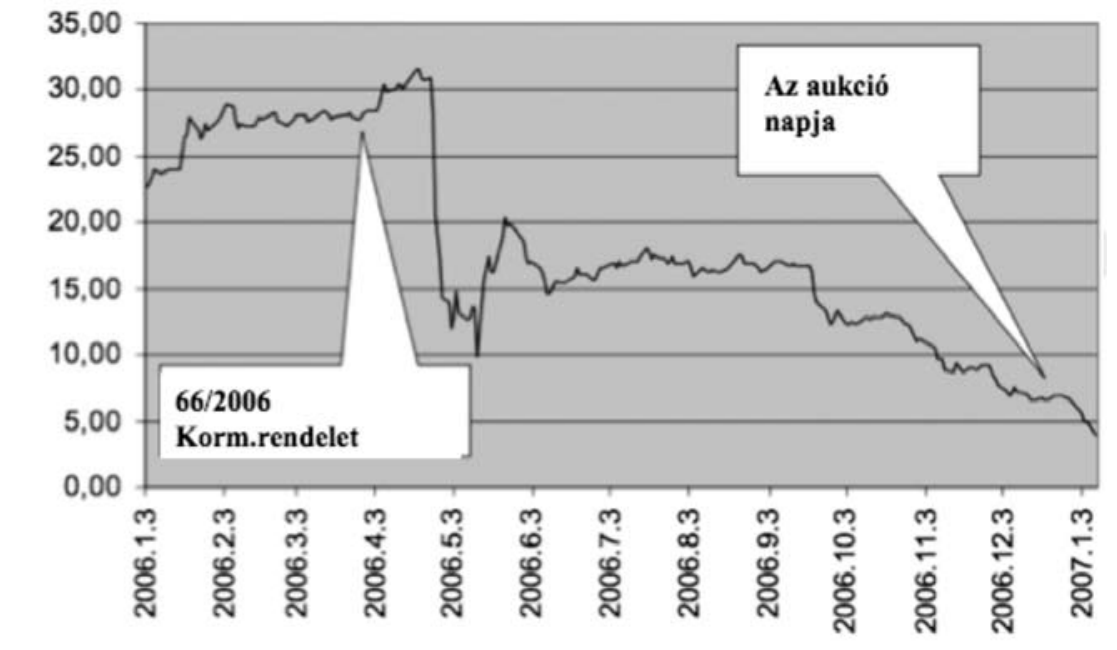

A Budapesti Corvinus Egyetem Regionális Energiagazdasági Kutatóközpontjának (REKK) munkatársai azt javasolták, hogy az értékesítés minél hamarabb történjen meg 2006-ban (REKK, 2006). Ezt az értékesítés kockázatának mérséklésével és a $\mathrm{CO}_{2}$-piacok keresleti és kínálati oldalán várható fundamentális hatásokkal

Az elsố aukció napjának ármozgása Forrás: Kaderják, 2007

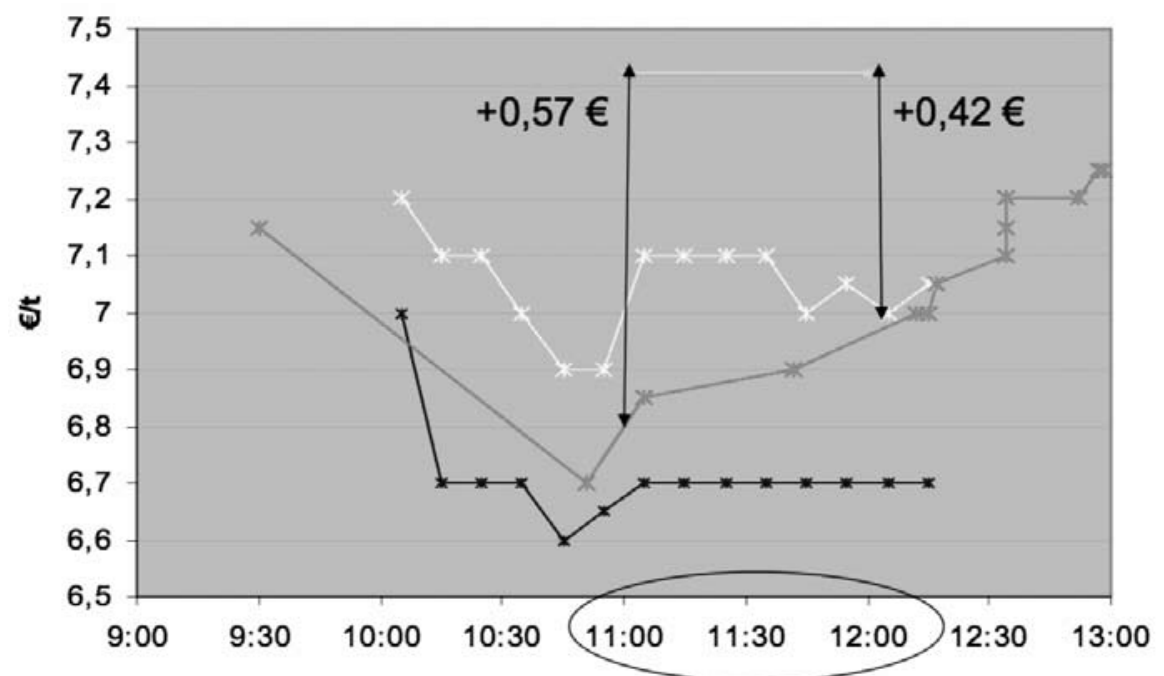

Best buy - Traded Auction's price

indokolták. Megállapíthatjuk, ha a tanulmányra hallgatott volna a magyar kormany, jelentósen nagyobb bevetelre tehettek volna szert.

A két árverés Magyarország számára tízmillió euró - több mint két és fél milliárd forint - bevételt hozott, aminek nagy részét a jogszabály szerint megújuló energiaforrások hasznosítását elómozdútó, illetajuló en anián ve englatakark fordítani. A KvVM-GKM és PM miniszterek erede megállapodása szerint az aukciós bevételekból egyegy milliárd forintot kapott a KvVM és a GKM az üvegházhatású gázook kibocsátásának csōkkentésével, kibocsátásának szabályozásával kapcsolatos felad tok, valamint a megújuló energiaforrások használatá ra és az energiafelhasználási hatékonyság javítására irányuló intézkedések finanszírozására, az e feletti összeg pedig a költségvetést gazdagította (KvVM, 2003 és 109/2006. [V. 5.] 8.§[7])

A Magyar Köztársaság költségvetési törvénye (2006. évi CXXVII. törvény 66.\$(4)) alapján a kibocsátási egységek értékesítésének bevételét a GKM

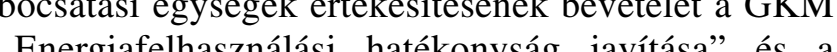
"EvVM „Üvegházhatású gázok kiboc javitása" és K VḾ „Ü kentésével ósszeflggo fela növelésére használták fel. A Kv M a bevetelek egy részével a kötelezó uniơs és nemzetközi jelentéstétel teljesítéséhez szükséges kölségeket fedezte, másrés a Nemzeti Éghajlatváltozási Stratégia elkészítéséhez kapcsolódó munkára használta fel, valamint konkrét, a magyarországi üvegházhatású gáz kibocsátásának csökkentésével kapcsolatos intézkedéseket valósították meg belóle.
A közgazdasági elmélet szerint az aukción a pici átagárnak kell kialakulnia (Klemperer, 2000; 2004). Az aukció résztvevoóinek lehetôségük lenne a karbontőzsdén is kibocsátási egységeket vásárolni, ezért nem valószínú a tôzsdei ár fölötti vételi ajánlat REKK, 2006). Érdekes, hogy a valóságban az elsố

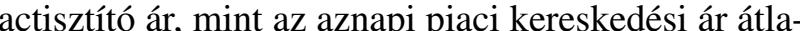
a (l.3. ábra).

Vajon mi okozhatta ezt az anomáliát? A REKK 2006) tanulmánya rámutat egy esetre, mely kivételt épezhet a szabály alól, amikor sok vevőnek olyan mennyiségben van szüksége kibocsátási egységekre, elyet rövid idó alatt csak jelentốs árfelhajtó hatás ellett toun alatt csak jelentós árfenajo hetben

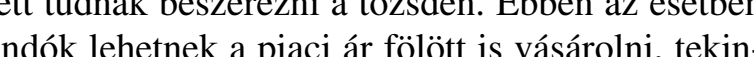
作landók lehetnek a piaci ár fölött is vásárolni, tekin-

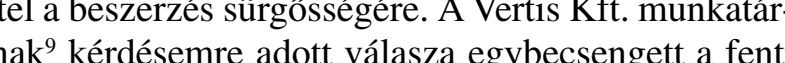
sának ${ }^{9}$ kérdésemre adott válasza egybecsengett a fent viveteles esettel, a magyar árverésen a piaci szereplók zert voltak hajlandók többet fizetni az egységekert, mert így nagyobb mennyiséghez juthattak hozzá. Ezt támasztja alá, hogy 2006 decemberében a licitálók 3,42 millió egységre tettek ajánlatot, majdnem háromzor annyira, mint az értékesíteni kívánt mennyiség, 2007 márciusában pedig 2,4 millió egységre licitáltak, zaz több mint kétszerese volt a kereslet az árverésre ocsátott mennyiségnek. Tehát a nagy mennyiségér arprémiumot is hajlandók voltak a vevók elfogadni. ${ }^{10}$ gyanakkor feltételezhetó - azonban a rendelkezésre âló információk alapján nem igazolható -, hogy külöldi vállalatok használták fel a magyarországi aukciós egysegeket hiannuk fedezésére (3. táblázat). 
Áttekintés az EU ETS próbaidószakának aukcióiról

\begin{tabular}{|c|c|c|c|}
\hline & Írország & Magyarország & Litvánia \\
\hline Aukciók száma & 2 & 2 & 1 \\
\hline \multirow{2}{*}{ Aukciók dátuma } & 2006. január 27. és & 2006. december 11. és & \multirow{2}{*}{ 2007. szeptember 10.} \\
\hline & 2006. december & 2007. március 27. & \\
\hline Aukciós tartalék (EUA) & 502201 & 791523 & 552000 \\
\hline Aukciós tartalék (\%) & $0,75 \%$ & $2,5 \%$ & $1,5 \%$ \\
\hline \multirow{2}{*}{ Elárverezett (EUA) } & 2006. január: 250000 & 2006. december: 1197000 & \multirow{2}{*}{552000} \\
\hline & 2006. december: 963000 & 2007. március: 1177500 & \\
\hline Elárverezett (\%) & $1,81 \%$ & $7,5 \%$ & $1,5 \%$ \\
\hline \multirow{2}{*}{ Ajánlati tétel nagysága } & 2006. január: 500 & \multirow{2}{*}{500} & \multirow{2}{*}{1000} \\
\hline & 2006. december: 1000 & & \\
\hline \multirow[t]{2}{*}{ Letét } & 2006. január: 3000 & \multirow[t]{2}{*}{$100 \%$} & \multirow{2}{*}{$100 \%$} \\
\hline & 2006. december: 15000 & & \\
\hline Aukció típusa & Zárt, borítékolt egyenáras & Zárt, borítékolt egyenáras & Zárt, borítékolt egyenáras \\
\hline \multirow{2}{*}{ Minimum ajánlati tétel (EUA) } & 2006. január: 500 & \multirow{2}{*}{1000} & \multirow{2}{*}{1000} \\
\hline & 2006. december: 1000 & & \\
\hline Minimum ajánlati érték (€) & n.a. & 1 eurocent & 1 eurocent \\
\hline Minimumár & n. a. & $\begin{array}{l}2006 \text { dec.: az elózó napi Point } \\
\text { Carbon } 2007 \text { EUA záróindexe } \\
\text { mínusz 0,9 € } \\
\text { 2007. márc.: az elózón napi } 2007 . \\
\text { dec.-i záro forward ár } 85 \% \text {-a, } \\
2 \text { tizedesre kerekítve }\end{array}$ & A piaci ár 85\%-a \\
\hline Résztvevók & $\begin{array}{l}\text { CITL-ben } \\
\text { számlával rendelkezók }\end{array}$ & $\begin{array}{l}\text { CITL-ben } \\
\text { számlával rendelkezők }\end{array}$ & $\begin{array}{l}\text { CITL-ben } \\
\text { számlával rendelkezók }\end{array}$ \\
\hline Rezervációs ár & Nem nyilvános & Nem nyilvános & Nem nyilvános \\
\hline \multirow{2}{*}{ Ajánlattételi idó́ } & 2006. január: 5 nap & \multirow{2}{*}{1 nap } & \multirow{2}{*}{1 nap } \\
\hline & 2006. december: 2 nap & & \\
\hline Elóhitelesítés & On-line, website & Nincs & Nincs \\
\hline \multirow{2}{*}{ Árverési ár ( $€ /$ tonna) } & 2006. január: 26,32 & 2006. december: 7,42 & \multirow{2}{*}{0,06} \\
\hline & 2006. december: 6,87 & 2007. március: 0,88 & \\
\hline
\end{tabular}

\section{Összefoglalás}

A 3. táblázat alapján megállapíthatjuk, hogy minden árverezó EU-tagállam egyforma aukciós technikát használt: egyenáras, zárt aukciókon értékesítette széndioxid-egységeit. Mindhárom aukción volt elő́re meghatározott minimumár. Mindhárom aukció minden számára nyitott volt, aki számlával rendelkezik a közösségi rendszerben (Community Independent Transaction Log, CITL). Egyik aukción sem hozták nyilvánosságra a rezervációs árat. A rezervációs ár meghatározása, közzététele több szempontból is kényes kérdés. Egyrészt közzététele nagyobb fokú átláthatóságot biztosí-

hat, s megóvhatja az aukció résztvevóit az előre nem látott eseményektől. Másrészt viszont közzé nem tétele arra ösztönözheti az ajánlattevôket, hogy összefogjaak, s ezen az áron licitáljanak.

A három árverező tagállam - Írország, Magyarrszág és Litvánia - hasonló tapasztalatokkal rendelkezik, míg a negyedik aukciós tartalékkal rendelkezô Dánia végül nem rendezett árverést. A dán kormány brókeren keresztül értékesítette egységeit a szén-dioxid-piacon. Levonhatjuk a következtetést, hogy a dán piaci ertékesítes sikeres volt abban a tekintetben, hogy az értékesítési ár magasabb volt, mint az ugyanazon idôszak átlagos piaci ára. Ưgy túnik tehát, hogy jó döntöttek, mikor profi brókerekre bízták a kibocsátási egységek értékesítését. Persze, ha még hamarabb bíztevést.

A másik három tagállam tapasztalatai hasonlóak, kijelenthetjük, hogy az EU szén-dioxid-piacának aukcionáló kormányai tanulási folyamaton mentek keresztül. Az aukciós elméletek s a piaci gyakorlat alapján levonhatunk néhány következtetést a kiotói időszak aukcióinak jobb és sikeresebb megvalósítása érdekében.

1) Az egyenáras aukciós technika egyszerú s átlátható ami megkönnyíti a részvevốk bekapcsolódását.

2) Az egyfordulós zárt forma, az, hogy az egyes ajánlattevớk nem látják egymás tétjeit, hatékonyan támogatja a piactisztító ár kialakulását, s véd az öszszefogástól.

3) Az egységeket jobb többször értékesíteni, negyedévente, ami a piaci árhoz közeli aukciós árat s magasabb likviditást biztosít.

4) 500 és 1000 egységes tételekben lehetett ajónlatokat tenni az egyes aukciókon, ez követhető a 2008 2012-es időszakban is. A nagyobb tételek csökkentik ugyan az adminisztratív költségeket, de kizárják voltak, ami kedvezett a verseny kialakulásának, $\mathrm{s}$ megakadályozta, hogy a résztvevốk összefogjanak.

A 4. táblázat összehasonlítja az egyes aukciók árait, $\mathrm{s}$ az éppen aktuális piaci árakat. Minden esetben igen közeli a két ár, mely alátámasztja, hogy a szén-dioxid-kibocsátási egységek nem a piactól elzárt egyedi jószágok, hanem homogén termékek, melyeket likvid másodlagos piacon is lehet adni-venni.

Összességében az idôzítés volt a legfontosabb az aukciók sikerének szempontjából, azaz a befolyt bevételek tekintetében. Írország nyerte a legtöbbet, mert ớk rendezték meg az árverést leghamarabb, már 2006 januáriában, mikor magasabb volt az elérhetố ár mint késóbbi idószakokban. Persze az aukciók terveź́sek

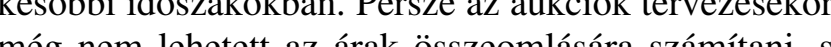
igen igy egy idôben egyen. legjobb megoldásnak. ták volna meg a brókereket, még magasabb bevétel tehettek volna szert, erősítette meg Pedersen úr a fela kisebb résztvevóket.

5) A megvalósult szén-dioxid-aukciók mind nyíltak

\section{Lábjegyzet}

A próbaidôszak tanulófázis, célja a kiotói idôszakra való felkészülés volt.

(HHI) a cégek métek a szerzók. A Herfindahl-Hirschman Index (Háśaban a cégek méretének mérószáma az adott iparág vonatkozásában, s megmutatja, milyen erós köztük a verseny. 0 -tól 1-ig
terjedhet, azaz sok kisméretú versenytárstól egészen egyetlen monopóliumig.

Ezen típusu aukciót William Vickrey Nobel-dijas közgazdászró nevezték el. O volt az elsó, aki a játékelméletet alkalmazta az aukciók megertésére. A gyakorlatban igen ritka a Vickrey aukció ( A droy, Il

A Energia Minisztérium fốtanácsadója, Sigurd

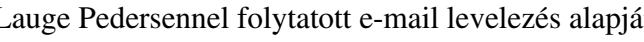

A teljes bevétel 8881740 euró volt, az aznapi árfolyam 256,2 的的 ésú . . Nemzeti Karbon Alap felállitítására, ahova az üvegházha-

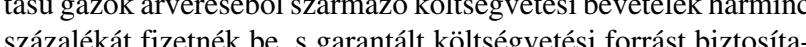

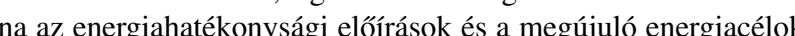
teljesítéséhez (Bizottsági támogatás a Karbon Alapnak c. cikk 2008. nov. 5. http.//www greenfo hu/kapcsolodo /kapcsolodo item.php?table $=$ hirek\&azonosito $=20016$ \&rovat $=$.

Feiler Józseffel, a Környezetvédelmi és Vízügyi Minisztérium Klímavédelmi és Energia Oszzályának oszzályvezetốjével 2008ban folytatott személyes beszélgetés alapján.

CSikesz Mariannal, a Veris Kh. konmunikációs menedzserével 2008-ban folytatott személyes beszélgetés alapján.

Sajnos arra vonatkozóan, hogy ki, milyen mennyiségben vásáA piaci árak a Vertis Zrt-tól származnak.

\section{Felhasznált irodalom}

Cason, T.N. Plott, C.R. (1996): EPA's New Emissions Trading Mechanism: A Laboratory Evaluation, Journal of Environmental Economics and Management, 30

. (1995): An Experimental Investigation of the Seller Incentives in EPA's Emission Trading Auction, A Developments in the European Union Emissions Trading Policy, 2007 1(1):88-111; doi:10.1093/reep/rem010

4. táblázat

A piaci és a piactisztító árak összevetése

\begin{tabular}{|l|c|c|c|c|}
\hline \multicolumn{1}{|c|}{$(\boldsymbol{\epsilon} /$ tonna) } & 2006. jan. 27. & 2006. december & 2007. márc. 27. & 2007. szept. 10. \\
\hline Piactisztító ár & 26,32 & $\begin{array}{c}\text { Írország: } 6,87 \\
\text { Magyarország: 7,42 }\end{array}$ & 0,88 & 0,06 \\
\hline Aznapi piaci ár ${ }^{11}$ & 26,10 & 7,10 & 0,98 & 0,06 \\
\hline
\end{tabular}

VEZETÉSTUDOMÁNY 
Cook, G. - Solsbery, L. - Cramton, P. - Ausubel, Lawrence M. (2005): EU ETS: Planning for auction or sale. For and on behalf of Environmental Resources Management, UK Department of Trade \& Industry

Cramton, P. - Kerr, S. (2002): Tradeable Carbon Permit Auctions. How and why to auction not grandfather. In Energy Policy, 30, 333-345. o.

Joskow, P.L. - Schmalensee, R. - Bailey, E.M. (1998): The Market for Sulfur Dioxide Emissions. American Economic Review 88(4): 669-685. o.

Joskow, P.L. -Schmalensee, R. (1998): The Political Economy of Market-Based Environmental Policy: The U.S. Acid Rain Program. Journal of Law and Economics, 41(1): 37-83. o.

Kaderják, $P$ (2007): Hungarian allowance sales in Phase 1. Presentation at the "EU ETS Workshop" at the University of Cambridge, on January 12

Klemperer, P. (2000): The Economic Theory of Auctions. Cheltenham, UK

Klemperer, P. (2002): What Really Matters in Auction Design. The Journal of Economic Perspectives 16: 169189. o.

Klemperer, P. (2004): Auctions: Theory and Practice. The Toulouse Lectures in Economics, Princeton University Press

Macken, K. (2006): Auctioning Allowances. Allowance Auction Workshop Presentations, New York Public Service Commission. Presented by Resources for the Future, 90 Church Street, NYC

Mandell, S. (2005): The choice of multiple or single auctions in emissions trading. Climate Policy 5(1) 97-107. o.

Pedersen, S.L. (2007): Auctioning experience in Denmark 2005-7 under the EU ETS, Danish Energy Authority. Preliminary and unofficial report

REKK (2006): Háttértanulmány a Magyar Állam tulajdonába tartozó, térítés ellenében kiosztásra kerülő szén-dioxid-kibocsátási egységek értékesítéséhez. Készítette a Budapesti Corvinus Egyetem Regionális Energiagazdasági Kutatóközpontja a Környezetvédelmi és Vízügyi Minisztérium megbízásából, Budapest

Vickrey, W. (1961): Counterspeculation, Auctions, and Competitive Sealed Tenders. Journal of Finance, 16: 8-37. o.

\section{Jogszabályok}

Communication from the Commission to the Council and to the European Parliament on the assessment of national allocation plans for the allocation of greenhouse gas emission allowances in the second period of the EU Emissions Trading Scheme accompanying Commission Decisions of 29 November 2006 on the national allocation plans of Germany, Greece, Ireland, Latvia, Lithuania, Luxembourg, Malta, Slovakia, Sweden and the United Kingdom in accordance with Directive 2003/87/EC (COM/2006/0725)

Proposal for a Directive amending Directive 2003/87/ EC so as to improve and extend the greenhouse gas emission allowance trading system of the Community (COM/2008/0016)

\section{On-line hivatkozások}

$\mathrm{CO}_{2}$ tốzsde, Budapest http://www.euets.com (2007. október 26.)

Európai Bizottság, Brüsszel $\mathrm{http} / / \mathrm{www} . e c . e u r o p a . e u / e n v i r o n m e n t /$ climat/2nd_phase_ep.htm (2007. november 13.) http://ec.europa.eu/environment/climat/emission/ ets_post2012_en.htm (2008. dec. 20.) http://ec.europa.eu/environment/climat/emission/ auctioning_en.htm (2009.jan. 20.)

Greenfo hírportál

http://www.greenfo.hu/kapcsolodo/

kapcsolodo_item.php?table=hirek\&azonosito= 20016\&rovat $=(2008$. november 5. $)$

Ír Környezetvédelmi Ügynökség http://www.epa.ie (2008. március 11.)

Point Carbon http://pointcarbon.com (többszöri letöltés 2007. szeptember 20. óta)

Vertis Környezetvédelmi Pénzügyi Tanácsadó Zrt. http://www.vertisfinance.com (2007. október 9.)

Cikk beérkezett: 2008. 11. hó

Lektori vélemény alapján véglegesítve: 2009. 3. hó 